\title{
INFLUENCE OF DISTILLERS DRIED GRAINS WITH SOLUBLES ON QUAIL MEAT PRODUCTIVITY
}

\author{
Anastasiia Plyska¹, Ildus Ibatullin¹, Mykhailo Sychov ${ }^{1}$

\begin{abstract}
${ }^{1}$ P.D. Pshenychnyy Department of Animal Nutrition and Feed Technology, Faculty of Livestock Raising and Water Bioresources, National University of Life and Environmental Sciences of Ukraine, 15, Heroyiv Oborony st., Kyiv, Ukraine
\end{abstract}

Link to this article: https://doi.org/10.11118/actaun.2021.029

Received: 10. 11. 2020, Accepted: 12. 4. 2021

To cite this article: PLYSKA ANASTASIIA, IBATULLIN ILDUS, SYCHOV MYKHAILO. 2021. Influence of Distillers Dried Grains With Solubles on Quail Meat Productivity. Acta Universitatis Agriculturae et Silviculturae Mendelianae Brunensis, 69(3): 319-326.

\begin{abstract}
One of the priority tasks of the agro-industrial complex in the modern world is to increase agricultural animal productivity and maximize the use of various processing byproducts in their feeding. Therefore, the experiment has been conducted to determine the influence of distillers dried grains with solubles as a part of feed mixtures on young quail meat productivity. To carry out the experiment, 5 groups, 100 quail heads in each, have been formed. Quails in the control group 1 did not receive distillers dried grains with solubles as a part of their feed mixture. Quails in the experimental groups 2, 3, 4 and 5 were fed by, respectively, $5 \%, 10 \%, 15 \%$, and $20 \%$ of distillers dried grains with solubles in complex with feed mixture. The experiment lasted for 35 days. Due to the daily body weight (thereinafter - BW) gain in average for the entire farming period, quails in the experimental group 5 gave in to quails in the control group by $0.16 \mathrm{~g}$ or $2.5 \%(\mathrm{P}<0.01)$, while the experimental group 2 outweighed them by $0.09 \mathrm{~g}$ or $1.4 \%$, group $3-$ by $0.19 \mathrm{~g}$ or $3 \%(\mathrm{P}<0.01)$, group 4 - by $0.13 \mathrm{~g}$ or $2.1 \%(\mathrm{P}<0.01)$. The lowest feed consumption per $1 \mathrm{~kg}$ of quail weight gain was observed in the experimental group 3, that gave in to quails in the control group by $78 \mathrm{~g}$ or $2.4 \%$. The experimental groups 2 and 4 had the same indicators, that gave in to quails in the control group by $31 \mathrm{~g}$ or $0.9 \%$. And only the experimental group 5 consumed $61 \mathrm{~g}$ or $1.8 \%$ more feed per $1 \mathrm{~kg}$ of BW gain in comparison to the control group. Evaluation of slaughter characteristics in quails, by means of complete feed mixtures with different content of distillers dried grains with solubles, has shown that the experimental group quails achieved the highest indicators.
\end{abstract}

Keywords: Pharaoh breed quails, feed conversion, livestock retention, slaughter rates

\section{INTRODUCTION}

Every single day, humans need more food, including animal source foods, but the planet resources are limited. That is why the priority task of world agriculture today is to increase agricultural animal productivity and maximize the use of various processing byproducts in feeding.

Distillers dried grain with solubles is a byproduct of bioethanol fermentation, which uses the dry milling technology for starch-rich grain such as corn. This is an excellent feed ingredient for cattle diet. This fact has been proved by many scientific studies and significant practical experience of its use in feeding of farm animals (Gunn et al., 2014; Masse et al., 2014; Tangendjaja, 2013). Distillers dried grain with solubles is valued for its significant protein content, which makes it a desirable feed ingredient for dairy cows diet (Tangendjaja, 2013). With the use of distillers dried grain with solubles, cow feeding becomes significantly cheaper and the productivity increases.

Distillers dried grain with solubles (thereinafter - bard) is also widely used in diets for pigs, as it contains a sufficient amount of proteins (Park et al., 2018; Rho et al., 2018). 
The bard contains all the nutrients of the original grain, their quantitative ratio is significantly different from the original, though.

On the minus side, energy nutrition of bard is lower comparing to cereals, but on the plus side, crude protein is 2.5 times higher, constituting a crude protein content of $26 \%$.

The bard has more fiber (15.1\%), fat (5.1\%) and crude ash (4.6\%) than grain. However, if this protein product is compared with oil meal and ground oil cake, it turns out that bard has an advantage over them, because it contains 2 times less fiber. It retains more than 18\% starch and up to $4 \%$ sugar.

Bard concentrates almost all amino acids, including essential ones. The content of lysine, methionine, threonine in the dry fermentation residue increases more than 2.5-3 times compared to the original grain.

Recently, in Ukraine and around the world, a significant amount of research has been conducted on the feasibility of using various corn processing byproducts in feeding of farm animals, including poultry: gluten flour (Seyedi et al., 2014), distillers dried grain with solubles (El-Abd et al., 2017; Konca et al., 2011; Schilling et al., 2010; Shim et al., 2018).

\section{MATERIALS AND METHODS}

The aim of the experiment was to study the influence of distillers dried grains with solubles on quail meat productivity. To carry out the experiment, 500 one-day old quails of the Pharaoh breed were selected. According to the analogy principle (by age and body weight), one control and four experimental groups of 100 heads in each were formed (Tab. I). The meat quail breed Pharaoh was developed by the American breeder A. Marsh. This is the first and the only pure meat breed, which is characterized by quite large carcasses suitable for culinary purposes.

The experiment lasted for 35 days and was divided into two periods ( $1^{\text {st }}-21^{\text {st }}$ days and $22^{\text {nd }}-35^{\text {th }}$ days) and 7 subperiods lasting 7 days each.

During the first experiment, quails were kept in single-tier battery cages. 25 heads were placed in each cage measuring $46 \times 40 \times 20 \mathrm{~cm}$. Given that, the floor area per head was $73.6 \mathrm{~cm}^{2}$. Cage frames provided a feeding front of at least $1.5 \mathrm{~cm}$. Vacuum drinkers were used to water the quails.

In the period from 1 to 21 days, artificial heating of quails was used at the temperature of $32-36{ }^{\circ} \mathrm{C}$, then the room temperature was $21-23^{\circ} \mathrm{C}$. The relative humidity at the rate $65-70 \%$. 24/7 lighting was applied in the first 3 weeks after birth. Subsequently, the length of light period is reduced by 3 hours during the week and set to 12 hours per 24-hour period. The experimental quails were given complete feed mixture; the feed nutrition corresponded to the recommended standards according to the age of the birds. The feed mixtures had a different percentage of the distillers dried grain with solubles added, and each recipe corresponded to the feeding standards for meat quails, which were developed by the Poultry Research Institute of the Ukrainian Academy of Agrarian Sciences (Ryabokon et al., 2005). The feed was given twice a day (in the morning and in the evening). Throughout the experiment, precise records of given feed and unconsumed residues were kept. In addition, the retention number of quails, their BW and growth, feed consumption per $1 \mathrm{~kg}$ of growth were recorded. At the end of the experiment, slaughter of experimental birds (4 heads from each group) was carried out and slaughter rates were studied. The slaughter was carried out by the method of decapitation.

The indicators to assess slaughter qualities of quails were the following:

- pre-slaughter weight - body weight of quails after 12-hour-fasting;

- ungutted carcass weight - carcass weight without blood and feathers;

- weight of half-gutted carcass - weight of carcass without blood, feathers and intestines;

- the weight of the gutted carcass - the weight of the carcass without blood, feathers, head, legs, wings on the elbow joint, intestines;

- weight of edible parts - the weight of all edible parts of gutted carcass;

- weight of internal fat.

The weight of slaughter products was determined using scales VLTK-500. On the basis of indicators for post-slaughter qualities of quails, indices of

I: Scheme of the experiment

\begin{tabular}{lccc}
\hline \multirow{2}{*}{ Group } & \multirow{2}{*}{$\begin{array}{c}\text { Number, heads } \\
\text { of livestock }\end{array}$} & \multicolumn{2}{c}{ Age, days } \\
\cline { 3 - 4 } & & Distillers dried grains with solubles content in feed mixtures, \% \\
\hline 1- control & 100 & - & - \\
2 - experimental & 100 & 5 & 5 \\
3 - experimental & 100 & 10 & 10 \\
4 - experimental & 100 & 15 & 15 \\
5 - experimental & 100 & 20 & 20 \\
\hline
\end{tabular}


meat qualities of carcasses were determined by the following:

- carcass meat - the ratio of the weight of all muscles to the weight of the gutted carcass, \%;

- breast meat - the ratio of the pectoral muscles weight to the weight of the gutted carcass, \%;

- leg meat - the ratio of the weight of leg muscles to the weight of the gutted carcass, \%;

- yield of edible parts - the ratio of all muscles weight to the weight of ungutted carcass, \%.

Feed mixtures were used to feed the experimental quails. Feed mixture recipes were composed in such a way that their nutritional value was the same. In this regard, the same set of ingredients (wheat, corn, barley, soybean meal, sunflower meal, distillers dried grains with solubles, sunflower oil, fish meal, gluten flour, blood flour, l-lysine, dl-methionine, monophonic salt, sodium chloride, mono-calcium phosphate, concentrate) was used, but in different proportions. Despite the slightly different composition of feed mixtures, their nutritional value was the same as shown in Tab. II.

Fluctuations in fat content were the most significant, as the use of significant amount of distillers dried grains with solubles into feed mixtures resulted in the need for more oil to balance the metabolic energy content.

The chemical composition of feed mixtures was carried out according to traditional methods:

- crude protein - using the Kjeldal method;

- crude fat - using the method of SV Rushkovsky, based on determining the amount of defatted

II: Energy and nutrient content per $1 \mathrm{~kg}$ of quail feed

\begin{tabular}{|c|c|c|c|c|c|c|c|c|c|c|}
\hline \multirow{3}{*}{ Indicator } & \multicolumn{10}{|c|}{ Quail group } \\
\hline & 1 & 2 & 3 & 4 & 5 & 1 & 2 & 3 & 4 & 5 \\
\hline & \multicolumn{5}{|c|}{ Quail age 1-21 days } & \multicolumn{5}{|c|}{ Quail age 22 days and more } \\
\hline $\mathrm{ME}, \mathrm{MJ} / \mathrm{kg}$ & 12.55 & 12.54 & 12.53 & 12.53 & 12.54 & 12.55 & 12.55 & 12.56 & 12.57 & 12.55 \\
\hline Crude protein, \% & 28.0 & 28.0 & 28.0 & 28.0 & 28.0 & 20.5 & 20.5 & 20.5 & 20.5 & 20.5 \\
\hline Crude fat, $\%$ & 5.0 & 5.6 & 5.6 & 5.6 & 5.6 & 5.3 & 5.3 & 5.4 & 5.9 & 6.4 \\
\hline Crude fiber, \% & 3.3 & 3.4 & 3.4 & 3.5 & 3.5 & 3.9 & 3.6 & 3.4 & 3.6 & 3.7 \\
\hline Lys, \% & 1.70 & 1.66 & 1.63 & 1.60 & 1.57 & 1.03 & 1.03 & 1.03 & 1.03 & 1.03 \\
\hline Met+Cys, \% & 1.02 & 1.01 & 1.03 & 1.04 & 1.05 & 0.83 & 0.83 & 0.83 & 0.83 & 0.83 \\
\hline Thr, $\%$ & 1.09 & 1.10 & 1.10 & 1.10 & 1.10 & 0.76 & 0.75 & 0.75 & 0.77 & 0.76 \\
\hline Trp, $\%$ & 0.32 & 0.31 & 0.31 & 0.30 & 0.29 & 0.21 & 0.21 & 0.20 & 0.19 & 0.19 \\
\hline Arg, $\%$ & 1.30 & 1.27 & 1.21 & 1.15 & 1.10 & 0.88 & 0.82 & 0.78 & 0.75 & 0.71 \\
\hline Val, \% & 1.43 & 1.43 & 1.43 & 1.44 & 1.44 & 0.89 & 0.88 & 0.88 & 0.89 & 0.89 \\
\hline His, \% & 0.91 & 0.92 & 0.91 & 0.91 & 0.91 & 0.53 & 0.53 & 0.53 & 0.54 & 0.54 \\
\hline Gly, \% & 1.06 & 1.05 & 1.07 & 1.09 & 1.10 & 0.73 & 0.70 & 0.68 & 0.68 & 0.67 \\
\hline Ile, $\%$ & 0.77 & 0.76 & 0.75 & 0.73 & 0.72 & 0.56 & 0.55 & 0.55 & 0.54 & 0.53 \\
\hline Leu, \% & 2.52 & 2.57 & 2.59 & 2.61 & 2.62 & 1.65 & 1.69 & 1.73 & 1.83 & 1.84 \\
\hline Phe, \% & 1.33 & 1.33 & 1.31 & 1.28 & 1.27 & 0.86 & 0.85 & 0.85 & 0.85 & 0.83 \\
\hline Tyr, \% & 0.83 & 0.83 & 0.82 & 0.81 & 0.80 & 0.56 & 0.57 & 0.57 & 0.58 & 0.57 \\
\hline $\mathrm{Ca}, \%$ & 1.0 & 1.0 & 1.0 & 1.0 & 1.0 & 1.0 & 1.0 & 1.0 & 1.0 & 1.0 \\
\hline P total, \% & 0.8 & 0.8 & 0.8 & 0.8 & 0.8 & 0.8 & 0.8 & 0.8 & 0.8 & 0.8 \\
\hline $\mathrm{Na}, \%$ & 0.34 & 0.34 & 0.41 & 0.45 & 0.49 & 0.3 & 0.3 & 0.3 & 0.4 & 0.4 \\
\hline $\mathrm{Cl}, \%$ & 0.26 & 0.27 & 0.31 & 0.34 & 0.38 & 0.2 & 0.2 & 0.2 & 0.3 & 0.3 \\
\hline $\mathrm{Cu}, \mathrm{mg}$ & 122 & 122 & 122 & 121 & 121 & 121 & 121 & 120 & 120 & 120 \\
\hline Zn, mg & 92 & 93 & 95 & 97 & 99 & 89 & 90 & 91 & 92 & 93 \\
\hline Mn, mg & 14 & 14 & 13 & 13 & 13 & 13 & 13 & 14 & 11 & 12 \\
\hline $\mathrm{Fe}, \mathrm{mg}$ & 354 & 334 & 332 & 319 & 306 & 236 & 204 & 184 & 175 & 164 \\
\hline
\end{tabular}

Biometric processing of data obtained during the research was performed using MS Excel 2013 software using built-in statistical functions. While processing the experimental data, the arithmetic mean $(M)$, its error $( \pm m)$ and the significance level (P) were calculated. To indicate the significance level of the probability criterion (P), the following symbols were used in the tables: ${ }^{*} \mathrm{P}<0.05,{ }^{* *} \mathrm{P}<0.01,{ }^{* * *} \mathrm{P}<0.001$ compared with the $1^{\text {st }}$ control group. 
residue in the Soxhlet apparatus, using benzol as a solvent;

- crude fiber - using the method of Henneberg and Shtoman;

- amino acid content - using an automatic analyzer TTT 339 using cation exchange resin LG ANB with active group SO3;

- the content of mineral elements - by spectral analysis using energy-dispersion X-ray fluorescence spectrometer "ElvaX".

Biometric processing of data obtained during the research was performed using MS Excel 2013 software using built-in statistical functions. While processing the experimental data, the arithmetic mean (M), its error $( \pm \mathrm{m})$ and the significance level (P) were calculated. To indicate the significance level of the probability criterion $(\mathrm{P})$, the following symbols were used in the tables: ${ }^{*} \mathrm{P}<0.05,{ }^{* *} \mathrm{P}<0.01$, *** $\mathrm{P}<0.001$ compared with the $1^{\text {st }}$ control group.

\section{RESULTS}

The main output of meat-type quails is the increase in BW (Tab. III). During the first week of life, quails of the experimental groups 2 and 5 made less progress comparing to the control group quails in terms of average daily weight gain, by $0.13 \mathrm{~g}$ and $0.19 \mathrm{~g}$, which is $4.0 \%$ and $6.0 \%$. During the same age period, quails of the experimental groups 3 and 4 outweighed control group quails by $0.06 \mathrm{~g}$ or $1.9 \%$ and $0.14 \mathrm{~g}$ or $4.4 \%$.

During the third week of growing, the results of quails in the $5^{\text {th }}$ group were lower compared to the control indicators over the daily body weight (BW) gain in average by $0.4 \mathrm{~g}$ or $5.0 \%$. At the same time, animals of the $2^{\text {nd }}, 3^{\text {rd }}$ and $4^{\text {th }}$ experimental groups, on the contrary, dominated over the control indicators by $0.55 \mathrm{~g}$ or $6.8 \%$ ( $\mathrm{P}<0.05), 0.50 \mathrm{~g}$ or $6.2 \%$ and $0.12 \mathrm{~g}$ or $1.5 \%$.

Only quails of the $5^{\text {th }}$ experimental group were inferior to the control indicators in terms of daily body weight (BW) gain in average by $0.17 \mathrm{~g}$ or $3.1 \%$ in the last week of breeding. Quails of the $2^{\text {nd }}, 3^{\text {rd }}$ and $4^{\text {th }}$ experimental groups prevailed over this indicator by $0.24 \mathrm{~g}, 0.43$ and $0.12 \mathrm{~g}$ which were $4.4 \%, 7.8$ and $2.2 \%$.

Thus, the daily body weight (BW) gain in average for the entire period of quails breeding of the $5^{\text {th }}$ experimental group was inferior to control analogues by $0.16 \mathrm{~g}$ or $2.5 \%(\mathrm{P}<0.01)$, whereas the animals of the $2^{\text {nd }}$ experimental group dominated them by $0.09 \mathrm{~g}$ or $1.4 \%, 3^{\text {rd }}-$ by $0.19 \mathrm{~g}$ or $3 \%$ $(\mathrm{P}<0.01), 4^{\text {th }}-$ by $0.13 \mathrm{~g}$ or $2.1 \%(\mathrm{P}<0.01)$.

The feed consumption indicator is important because its impact on quail productivity is significant (Tab. IV).

Analyzing the average daily feed intake of quails in general for the entire period of the experiment

III: Dynamics of daily body weight (BW) gain in average, $g$

\begin{tabular}{|c|c|c|c|c|c|}
\hline \multirow{3}{*}{ Age, days } & \multicolumn{5}{|c|}{ Quail group } \\
\hline & \multirow{2}{*}{$\begin{array}{c}\text { Control } \\
1\end{array}$} & \multicolumn{4}{|c|}{ Experimental } \\
\hline & & 2 & 3 & 4 & 5 \\
\hline $1-7$ & $3.19 \pm 0.090$ & $3.06 \pm 0.078$ & $3.25 \pm 0.081$ & $3.33 \pm 0.063$ & $3.00 \pm 0.076$ \\
\hline $8-14$ & $6.91 \pm 0.127$ & $6.86 \pm 0.090$ & $6.91 \pm 0.115$ & $7.14 \pm 0.150$ & $6.93 \pm 0.105$ \\
\hline $15-21$ & $8.03 \pm 0.167$ & $8.58 \pm 0.172 *$ & $8.53 \pm 0.182$ & $8.15 \pm 0.185$ & $7.63 \pm 0.185$ \\
\hline $22-28$ & $8.06 \pm 0.207$ & $7.93 \pm 0.199$ & $8.06 \pm 0.204$ & $8.13 \pm 0.202$ & $7.94 \pm 0.218$ \\
\hline $29-35$ & $5.48 \pm 0.182$ & $5.72 \pm 0.191$ & $5.91 \pm 0.212$ & $5.60 \pm 0.242$ & $5.31 \pm 0.207$ \\
\hline $1-35$ & $6.34 \pm 0.035$ & $6.43 \pm 0.038^{* *}$ & $6.53 \pm 0.049^{* *}$ & $6.47 \pm 0.036^{* *}$ & $6.18 \pm 0.042^{* *}$ \\
\hline
\end{tabular}

Here and further $* \mathrm{P}<0.05,{ }^{* *} \mathrm{P}<0.01$

IV: Average daily feed consumption, g/age/days

\begin{tabular}{cccccc}
\hline & \multicolumn{5}{c}{ Quail group } \\
\cline { 2 - 5 } Age, days & Control & \multicolumn{4}{c}{ Experimental } \\
\cline { 2 - 5 } & 1 & 2 & 3 & 4 & 5 \\
\hline $1-7$ & 4.61 & 4.58 & 4.62 & 4.69 & 4.55 \\
$8-14$ & 15.74 & 15.62 & 15.77 & 15.77 & 15.75 \\
\hline $15-21$ & 21.38 & 21.92 & 21.85 & 21.41 & 20.98 \\
\hline $2-28$ & 30.05 & 29.85 & 30.05 & 30.63 & 29.73 \\
\hline $29-35$ & 35.37 & 36.13 & 36.53 & 35.86 & 25.19 \\
\hline $1-35$ & 21.43 & 21.62 & 21.76 & 21.67 & 19.24 \\
\hline
\end{tabular}


(35 days), it should be noted that the highest rate was in quails of the $3^{\text {rd }}$ experimental group $-0.33 \mathrm{~g}$ or $1.5 \%$ higher than control group. Quails of the $2^{\text {nd }}$ and $4^{\text {th }}$ experimental groups consumed a similar amount of feed, which is $0.19 \mathrm{~g}$ and $0.24 \mathrm{~g}(0.9$ and $1.1 \%)$ more than the control group. Quails of the $5^{\text {th }}$ experimental group consumed much less than control group, namely on $2.19 \mathrm{~g}$ or $10.2 \%$.

During the whole period of the experiment, the quails of the $3^{\text {rd }}$ experimental group consumed the most feed - $761.7 \mathrm{~g} /$ age/experiment, and the least - of the $5^{\text {th }}$ experimental group - $673.4 \mathrm{~g} / \mathrm{age} /$ experiment. Quails of the $2^{\text {nd }}$ and $4^{\text {th }}$ experimental groups consumed 756.7 and $758.5 \mathrm{~g}$ /age/experiment. The control quail group consumed $750.1 \mathrm{~g} / \mathrm{age} /$ experiment.

An important economic and analytical indicator is the consumption of feed per $1 \mathrm{~kg}$ of body weight gain. Analyzing the results of calculating feed consumption per $1 \mathrm{~kg}$ of quails' body weight gain for giving feed mixtures with distillers dried grains with solubles (Tab. V), it was found that during the first week of life, the least feed for growth was spent by the $4^{\text {th }}$ experimental quail group $-0.035 \mathrm{~g}$ or $2.4 \%$ less than control group. This indicator was also lower in the $3^{\text {rd }}$ experimental quail group - by $0.023 \mathrm{~g}$ or $1.6 \%$. In the $2^{\text {nd }}$ and $5^{\text {th }}$ experimental quail groups this indicator exceeded the control group by $0.054 \mathrm{~g}$ or $3.7 \%$ and $0.071 \mathrm{~g}$ or $4.9 \%$.

During the third week of breeding, only the quails of the $5^{\text {th }}$ experimental group exceeded the control birds in terms of feed consumption per $1 \mathrm{~kg}$ of BW gain - by $0.060 \mathrm{~g}$ or $2.3 \%$. On the other hand, quails of the $2^{\text {nd }}, 3^{\text {rd }}$ and $4^{\text {th }}$ experimental groups were inferior to control group by $0.107 \mathrm{~g}, 0.100$ and 0.036 g respectively, which is $4.0 \%, 3.8$ and $1.4 \%$ in percentage terms.

The feed consumption per $1 \mathrm{~kg}$ of body weight gain of the $3^{\text {rd }}$ experimental group at the age of 22-28 days was equal to the control group. In the $2^{\text {nd }}, 4^{\text {th }}$ and $5^{\text {th }}$ groups, the consumption of feed exceeded the control indicator by $0.038 \mathrm{~g}, 0.042$ and $0.016 \mathrm{~g}$ or by $1.0 \% 1.1$ and $0.4 \%$.

In the last week of quail breeding, the lowest feed consumption was in the $3^{\text {rd }}$ quail experimental group - by $0.274 \mathrm{~g}$ or $4.2 \%$ less than the $1^{\text {st }}$ control quail group. During this period, the highest control indicator was only in the $5^{\text {th }}$ experimental quail group - by $0.164 \mathrm{~g}$ or $2.5 \%$. In the $2^{\text {nd }}$ and $4^{\text {th }}$ experimental quail groups, feed consumption per $1 \mathrm{~kg}$ of BW gain was lower by $0.141 \mathrm{~g}$ or $2.2 \%$ and $0.053 \mathrm{~g}$ or $0.8 \%$ than the control quail groups.

In general, for the entire 35-day-period of the experiment, the lowest feed consumption per $1 \mathrm{~kg}$ of weight gain was in the $3^{\text {rd }}$ experimental quail group. According to this indicator, they were inferior to control group by $78 \mathrm{~g}$ or $2.4 \%$. The $2^{\text {nd }}$ and $4^{\text {th }}$ experimental quail groups had the same indicators, which were inferior to the control group by $31 \mathrm{~g}$ or $0.9 \%$. And only the $5^{\text {th }}$ experimental quail group consumed $61 \mathrm{~g}$ or $1.8 \%$ more feed per $1 \mathrm{~kg}$ of growth than the control quail group.

During the experiment, livestock retention number was recorded on regular basis. To do this, the experimental poultry was inspected daily, dead individuals were removed. It should be noted that the retention number in all groups was at a high level of 97-98\%.

The purpose of breeding the meat-type quails is the production of meat. Therefore, the analysis of slaughter quail rates is important (Tab. VI). The yield of slaughter products in percentage to the pre-slaughter weight was analyzed. Only the quails of the $3^{\text {rd }}$ experimental group outweighed the control indicator of the pectoral muscles by $0.08 \%$. Quails of the $2^{\text {nd }}, 4^{\text {th }}$ and $5^{\text {th }}$ experimental groups were $0.08 \%$, 0.63 and $0.28 \%$ inferior to the $3^{\text {rd }}$ group. In terms of leg muscle output, experimental quail groups were inferior to control groups. This indicator in quails of the $2^{\text {nd }}$ experimental group was lower than the control indicator by $0.64 \%$, the $3^{\text {rd }}$ experimental quail group - by $0.68 \%$, the $4^{\text {th }}$ experimental quail group - by $1.84 \%(\mathrm{P}<0.01)$, the $5^{\text {th }}$ experimental group - $1.29 \%(\mathrm{P}<0.05)$.

The highest yield of internal fat was marked by quails of the $1^{\text {st }}$ control group, as 2-; 3-; 4- and $5^{\text {th }}$ experimental quail groups were inferior to this indicator by $0.03 \%$; $0.19 ; 1.15$ and $0.1 \%$.

Liver yield of the $2^{\text {nd }}$ and $3^{\text {rd }}$ experimental quail groups was higher than control indicator by 0.22

V: Feed costs per $1 \mathrm{~kg}$ of body weight (BW) gain, $\mathrm{kg}$

\begin{tabular}{cccccc}
\hline & \multicolumn{5}{c}{ Quail group } \\
\cline { 2 - 6 } Age, days & Control & \multicolumn{4}{c}{ Experimental } \\
\cline { 2 - 6 } & 1 & 2 & 3 & 4 & 5 \\
\hline $1-7$ & 1.445 & 1.499 & 1.422 & 1.410 & 1.516 \\
$8-14$ & 2.277 & 2.277 & 2.283 & 2.207 & 2.274 \\
\hline $15-21$ & 2.662 & 2.555 & 2.562 & 2.626 & 2.722 \\
\hline $2-28$ & 3.727 & 3.765 & 3.727 & 3.769 & 3.743 \\
\hline $29-35$ & 6.457 & 6.316 & 6.183 & 6.404 & 6.621 \\
\hline $1-35$ & 3.314 & 3.283 & 3.236 & 3.283 & 3.375 \\
\hline
\end{tabular}




\begin{tabular}{lccccc}
\hline \multirow{2}{*}{ Index } & \multicolumn{5}{c}{ Quail groups } \\
\cline { 2 - 6 } & \multicolumn{2}{c}{ Control } & \multicolumn{4}{c}{ Experimental } \\
\cline { 2 - 6 } & \multicolumn{1}{c}{1} & 2 & 3 & 4 & 5 \\
\hline Yield of half-gutted carcase & $81.24 \pm 0.290$ & $81.36 \pm 0.870$ & $81.33 \pm 0.530$ & $79.83 \pm 0.330^{*}$ & $80.17 \pm 0.340$ \\
The output of the dressed carcase & $76.34 \pm 0.280$ & $77.49 \pm 0.340$ & $76.41 \pm 0.550$ & $75.13 \pm 0.240^{*}$ & $75.67 \pm 0.480$ \\
\hline & \multicolumn{2}{c}{ Yield of edible parts: } & & \\
\hline Pectoral muscles & $16.16 \pm 0.25$ & $16.08 \pm 0.340$ & $16.24 \pm 0.450$ & $15.53 \pm 0.160$ & $15.88 \pm 0.430$ \\
\hline Leg muscles & $11.93 \pm 0.280$ & $11.29 \pm 0.210$ & $11.25 \pm 0.290$ & $10.09 \pm 0.240^{* *}$ & $10.64 \pm 0.220^{*}$ \\
\hline Skin & $7.28 \pm 0.260$ & $7.57 \pm 0.120$ & $6.54 \pm 0.210$ & $7.33 \pm 0.310$ & $7.44 \pm 0.260$ \\
\hline Internal fat & $1.44 \pm 0.070$ & $1.41 \pm 0.050$ & $1.25 \pm 0.030$ & $1.29 \pm 0.080$ & $1.34 \pm 0.060$ \\
Liver & $2.42 \pm 0.250$ & $2.64 \pm 0.150$ & $2.52 \pm 0.210$ & $2.08 \pm 0.190$ & $2.00 \pm 0.070$ \\
Lungs & $0.81 \pm 0.070$ & $0.99 \pm 0.070$ & $0.80 \pm 0.060$ & $0.77 \pm 0.050$ & $0.80 \pm 0.040$ \\
Kidneys & $0.70 \pm 0.070$ & $0.73 \pm 0.040$ & $0.54 \pm 0.050$ & $0.64 \pm 0.040$ & $0.62 \pm 0.050$ \\
\hline Muscular stomach & $1.62 \pm 0.210$ & $1.72 \pm 0.100$ & $1.66 \pm 0.090$ & $1.67 \pm 0.090$ & $1.72 \pm 0.040$ \\
\hline Heart & $0.95 \pm 0.050$ & $1.04 \pm 0.050$ & $0.91 \pm 0.060$ & $0.94 \pm 0.040$ & $0.91 \pm 0.050$ \\
\hline
\end{tabular}

VII: Meat indices

\begin{tabular}{lccccc}
\hline \multirow{2}{*}{\multicolumn{1}{c}{ Index }} & \multicolumn{5}{c}{ Quail groups } \\
\cline { 2 - 6 } & \multicolumn{1}{c}{ Control } & \multicolumn{4}{c}{ Experimental } \\
\cline { 2 - 6 } & 1 & 2 & 3 & 4 & 5 \\
\hline Carcase meatiness & $52.4 \pm 1.12$ & $49.9 \pm 0.72$ & $50.7 \pm 1.46$ & $47.5 \pm 0.57^{*}$ & $49.1 \pm 0.86$ \\
Breast meat & $21.2 \pm 0.36$ & $20.7 \pm 0.36$ & $21.3 \pm 0.64$ & $20.7 \pm 0.25$ & $21.0 \pm 0.47$ \\
Leg meat & $15.6 \pm 0.43$ & $14.6 \pm 0.26$ & $14.7 \pm 0.42$ & $13.4 \pm 0.30^{*}$ & $14.1 \pm 0.21^{*}$ \\
Output of edible parts & $72.4 \pm 1.82$ & $70.7 \pm 0.79$ & $69.3 \pm 1.49$ & $67.1 \pm 0.58$ & $68.7 \pm 0.67$ \\
Bones & $27.6 \pm 1.82$ & $29.3 \pm 0.79$ & $30.7 \pm 1.49$ & $32.9 \pm 0.58$ & $31.3 \pm 0.67$ \\
\hline
\end{tabular}

and $0.10 \%$, while in the $4^{\text {th }}$ and $5^{\text {th }}$ experimental quail groups - lower by 0.34 and $0.42 \%$.

Lungs and hearts yield had a similar tendency. Control indicator was exceeded only in the $2^{\text {nd }}$ experimental quail group - by 0.28 and $0.09 \%$. Quails of the $3^{\text {rd }}$ and $5^{\text {th }}$ experimental groups had identical indicators of lung and heart yield, which were inferior to control indicator by 0.01 and $0.04 \%$ and also the $4^{\text {th }}$ experimental group was inferior to control indicator by 0.04 and $0.01 \%$.

The quails of the $2^{\text {nd }}$ and $5^{\text {th }}$ experimental groups had the same output of the muscular stomach, which was higher than the control indicator by $0.10 \%$. Quails of the $3^{\text {rd }}$ and $4^{\text {th }}$ experimental groups were very similar in terms of gastric muscle yield and exceeded the control group by 0.04 and $0.05 \%$.

Meat indices are an additional indicator of the poultry meat quality. The total yield of edible parts (Tab. VII) was the highest in quails of the $1^{\text {st }}$ control group. Therefore animals 2-; 3-; 4- and $5^{\text {th }}$ experimental groups were inferior to them in the yield of edible parts by $1.7 ; 3.1 ; 5.3$ and 3.7 or 2.3\%; $4.3 ; 7.3$ and $5.1 \%$.
According to the carcase meat index, the advantage of control group over quails in 2-; 3-; 4- and 5 experimental groups were $2.5 ; 1.7 ; 4.9(\mathrm{P}<0.05)$ and 3.3, which in percentage terms is $4.8 \% ; 3.2 ; 9.4$ $(\mathrm{P}<0.05)$ and $6.3 \%$.

The index of breast meat was the same in birds of the $2^{\text {nd }}$ and $4^{\text {th }}$ experimental groups and lower than the control indicator by 0.5 or $2.4 \%$. Quails of the $5^{\text {th }}$ experimental group also lost to control group over this indicator - by 0.2 or $0.9 \%$. And only the quails of the $3^{\text {rd }}$ experimental group outperformed the control analogues in the breast meat index by 0.01 or $0.5 \%$.

The $1^{\text {st }}$ control quail group was dominated by the experimental groups of leg meat. So the 2-; 3-; 4 - and $5^{\text {th }}$ experimental quail groups were inferior to them in this index by $1.0 ; 0.9 ; 2.2(\mathrm{P}<0.05)$ and 1.5 units $(\mathrm{P}<0.05)$, which is 6.4\%; 5.8; $14.1(\mathrm{P}<0.05)$ and $9.6 \%(\mathrm{P}<0.05)$.

Thus, the assessment of slaughter quail qualities for giving feed mixtures of distillers dried grains with solubles showed that the highest rates were achieved by the $3^{\text {rd }}$ experimental quail group. 


\section{DISCUSSION}

In our studies, a positive effect of giving feed mixtures with a content of $5-15 \%$ of distillers dried grains with solubles to quails was noted. Similar conclusions were reached by other scientists. Thus, scientists (Konca et al., 2011) claim that among the studied levels of distillers dried grains with solubles in quail feed, which is 10\%, 20 and 30\%, the highest productivity was achieved by those who consumed feed containing $20 \%$ of distillers dried grains with solubles.

El-Abd et al. (2017) publish scientific papers showing the positive effects of including both 30\% and $60 \%$ of distillers dried grains with solubles in quail feed. In this case, the highest absolute increase more than $9.1 \%$ comparing to the control group is when distillers dried grains with solubles constitute $60 \%$ in the feed mixture. And with a share of 30\% increase in absolute growth is 8.1\%.

A number of scientists in their studies on broiler chicken have shown that the feeding of $4 \%$ and $6 \%$ PVMA (protein-mineral-vitamin supplement), which includes $45 \%$ of distillers dried grains with solubles as part of the feed, helps to increase the average daily gain by 0.5 and $1.2 \%$ (Ulitko et al., 2010). The results of other studies, conducted in Russia (Egorov et al., 2004), showed that the feeding of broiler chicken with addition of $4 \%$ and $6 \%$ of distillers dried grains with solubles from barley, helps to increase the average BW gain by 2.7 and $2.0 \%$.

Thus, the results of our research are conformed on the experimental data of foreign scientists on the positive effect of distillers dried grains with solubles in the feed on the quail growth. However, it should be noted that in our studies, increasing the content of distillers dried grains with solubles to $20 \%$ had a negative impact on the productivity of quails relative to control indicator; and in the experiments of foreign researchers even at 30\% and $60 \%$ of this feed in the diet of meat-type quails their daily BW gain exceeded the control group.

Increasing the growth quail rate can occur only with the accumulation of more nutrients in the tissues of their body. Therefore, quails should either consume more food or better digest its nutrients. In our research it was noted that quails of a meat type consumed more feed, namely: at the level of $5 \%$ of distillers dried grains with solubles in a feed mixture - by $0,9 \%, 10 \%$ - by $1.5 \%, 15 \%$ - by 1 , $1 \%$ compared to the control group. Quails whose feed contained $20 \%$ of distillers dried grains with solubles consumed $10.2 \%$ less feed than control quail group. At the same time, per $1 \mathrm{~kg}$ of $\mathrm{BW}$ gain, quails consumed: including $5 \%$ and $15 \%$ of distillers dried grains with solubles in the diet $0.9 \%$ less feed than control quail group, $10 \%$ of distillers dried grains with solubles $-2.4 \%$ less feed, and $20 \%$ distillers dried grains with solubles $-1.8 \%$ more feed.

In the studies El-Abd et al. (2017) it was noted that when the content of distillers dried grains with solubles constituted $30 \%$ of feed mixture, quails consumed $1.2 \%$ more feed, but its cost per kilogram of growth decreased by $6.4 \%$. Increasing the share of distillers dried grains with solubles in feed to $60 \%$ helped increase the amount of feed consumed by $3.8 \%$ and reduce its costs by $4.9 \%$. A similar tendency may be seen in studies conducted by scientists on broiler chickens (Ulitko et al., 2010). Thus, birds, whose feed mixtures contained 4\% and 6\% PVMA (protein-mineral-vitamin suplement), adding $45 \%$ of distillers dried grains with solubles, consumed it more than control animals by $1.6 \%$. Egorova T. noted that giving broiler chickens feed mixtures with a content of $4 \%$ and $6 \%$ of distillers dried grains with solubles from barley helps to reduce feed consumption per kilogram of growth by 2.9 and 3.4\% (Egorov et al., 2004).

Considerable attention was paid to slaughter qualities in the course of scientific and economic experiment. Konca et al. (2011) have paid a lot of attention to the slaughter qualities of quails and the quality of meat while the consumption of $10-30 \%$ of distillers dried grains with solubles used in feed mixtures. They noted a statistically significant decrease in the mass of the pancreas and cecum, an increase in the dry matter content of meat. The fat content of the meat varied and each difference with the control group was statistically significant. There was also a tendency of the proportion increase of ash and protein in meat.

El-Abd et al. (2017) reported a tendency of decrease in the relative mass of the liver and muscle stomach, as well as increase in the relative mass of the heart by $30 \%$ and $60 \%$ of distillers dried grains with solubles in feed mixture.

Experiments on broiler chicken conducted by a group of scientists (Ulitko et al., 2010) showed a slight moisture increase in white meat and a decrease of this indicator in red meat, as well as a slight increase in protein and a decrease in the proportion of ash for feeding $4 \%$ and $6 \%$ of PVMA (protein-mineral-vitamin supplement), which contained $45 \%$ of distillers dried grains with solubles. Researchers (Schilling et al., 2010) reported a slight increase in fat and a decrease in the proportion of moisture and protein in the pectoral muscles when feeding broiler chicken with 6\%, $12 \%, 18 \%$ and $24 \%$ of distillers dried grains with solubles. Instead, the leg muscles of these chickens showed a slight decrease in fat, an increase in humidity and fluctuations in protein content, both upward and downward. 


\section{CONCLUSION}

Our results provide evidence that giving young quails of meat type the complete feed mixture with a content of $10 \%$ distillers dried grains with solubles helps to increase the average daily gain of their BW by 3.0\% ( $<<0.01$ ); as well as reduce feed costs per $1 \mathrm{~kg}$ of body weight gain per $2.4 \%$. At the same time, the use of feed with a content of 15\% bard helps to reduce the yield of dressed carcase and leg muscles and reduces the meat index of the carcase by $4.9 \%(\mathrm{P}<0.05)$ and the index of leg meat by $2.2 \%(\mathrm{P}<0.05)$.

\section{REFERENCES}

EGOROV, I. and EGOROVA, T. 2004. Dried distillers grains with solubles in the diet of broilers and laying hens [in Russian: Сухая зерновая барда в рационе бройлеров и кур-несушек]. Poultry: Scientific and Production Journal, 9: 17-20.

EL-ABD, N. M. 2017. Yellow corn replaced by distillers dried grains with solubles (DDGS) of dietary japanese quail. Egyptian Poultry Science Journal, 37(2): 451-460.

GUNN, P. J., LEMENAGER, R. and BRIDGES, A. 2014. Excess rumen undegradable protein alters parameters of reproductive function in beef cows. Iowa State University Animal Industry Report No. 11. Iowa State University.

KONCA, Y., KIKPINAR, F. and MERT, S. 2011. Effects of corn distillers dried grain with solubles (DDGS) on carcass, meat quality and intestinal organ traits in japanese quails. Scientific Papers seria D Animal science, 54: 39-44.

MASSE, D. I., JARRET, G., BENCHAAR, C. and CATA SAADY, N. M. 2014. Effect of Corn Dried Distiller Grains with Solubles (DDGS) in Dairy Cow Diets on Manure Bioenergy Production Potential. Animals, 4(1): 82-92.

PARK, C. S., RAGLAND, D. and ADEOLA, O. 2018. Amino acid digestibility of corn distillers' dried grains with solubles with the addition of casein in pigs. Journal of Animal Science, 96(11): 4674-4684.

RHO, Y., WEY, D., ZHU, C., KIARIE, E., MORAN, K., VAN HEUGTEN, E. and DE LANGE, C. F. M. 2018. Growth performance, gastrointestinal and digestibility responses in growing pigs when fed cornsoybean meal-based diets with corn DDGS treated with fiber degrading enzymes with or without liquid fermentation. Journal of Animals Science, 96(12): 5188-5197.

RYABOKON, Y., BRATYSHKO, N., HOROBETS, A. and PRYTULENKO, O. 2005. Recommendations for rationing of poultry feeding [in Ukrainian: Рекомендації 3 нормування годівлі сільськогосподарської птиці]. Berky.

SCHILLING, M. W., BATTULA, V., LOAR, R. E., JACKSON, V., KIN, S. and CORZO, A. 2010. Dietary inclusion level effects of distillers dried grains with solubles on broiler meat quality. Poultry Science, 89(4): 752-760.

SEYEDI, A. H. and HOSSEINKHANI, A. 2014. Evaluation corn gluten meal nutritive value for broiler chicks. International Journal of Advanced Biological and Biomedical Research, 2(9): 2609-2615.

SHIM, Y., KIM, J., HOSSEINDOUST, A., CHOI, Y., KIM, M., OH, S., HAM, H., KUMAR, A., KIM, K., JANG, A. and CHAE, B. 2018. Investigating meat quality of broiler chickens fed on heat processed diets containing corn distillers dried grains with solubles. Korean Journal for Food Science of Animal Resources, 38(3): 629-635.

TANGENDJAJA, B. 2013. Effect of feeding corn dried distillers grains with solubles (DDGS) on milk production of cow under hot climate condition. Indonesian Journal of Agricultural Science, 14(2): 63-70.

ULITKO, V. E. and ERISANOVA, O. E. 2010. Growth, slaughter and meat quality of broilers when used in rations of PVMA based on dried distillers grains with solubles [in Russian: Рост, убоиные и миасные качества бройлеров при использовании в рациях БВМд на основе сухой спиртовой барды]. Bulletin of USAA, 1(11): 43-48.

\section{Contact information}

Mykhailo Sychov: sychov@ukr.net (corresponding author)

Anastasiia Plyska: plyska.a@agro.globino.ua

Ildus Ibatullin: ibatullin@nubip.edu.ua 